\title{
THE NATION OR THE 'LOCAL ORGANIC COMMUNITY'?: Ó CADHAIN VERSUS Ó DROIGHNEÁIN
}

\author{
FIONNTÁN DE BRÚN
}

\section{Introduction}

While the phrase 'Ó Cadhain versus Ó Droighneáin' is admittedly fictive, suggesting, as it does, the title of a putative court case or heavy-weight boxing bout, I hope the intention may be forgiven insofar as Máirtín Ó Cadhain and Muiris Ó Droighneáin were indeed heavy-weights in the discourse of the Irish language in the twentieth century and both were inveterate polemicists, driven by a belief in the justice of their respective positions. Of the two, Máirtín Ó Cadhain, writer and political activist, is by far the most recognised and celebrated today, yet the legacy of the teacher and grammarian, Muiris Ó Droighneáin, while less obvious, is nevertheless very far-reaching. My intention in this paper is to focus on an exchange of articles published in $A n$ tUltach magazine in 1962 in which both men expressed trenchant views on the use of Standard Irish. ${ }^{1}$ The importance of these short articles, in my opinion, is to illuminate polarities within the Irish nationalist project, a project to which both men subscribed, physically and intellectually.

Firstly some brief biographical notes. ${ }^{2}$ Máirtín Ó Cadhain was born in 1906, a native of the Cois Fharraige Gaeltacht, in Co. Galway and died in

\footnotetext{
${ }^{1}$ Ó Droighneáin (1962a; 1962b); Ó Cadhain (1962). Ó Cadhain wrote a further article in reply to Ó Droighneáin (1962b) but this was not published by An tUltach. This may have been due to a number of factors including references to the word banéigean or 'rape', which may have been considered inappropriate by the editor of An tUltach, given that the magazine depended on a large school-based readership, or the claim made by Ó Cadhain that Ó Droighneáin had gone on a linguistic spying mission to Ó Cadhain's family home in Cois Fharraige! This claim is interesting in the light of a later remark by Ó Cadhain (1969: 15) that "People go to my house in Cois Fharraige and among my neighbours to enquire there if my speech is the speech of my people" (My translation. Similarly, all other translation in this article of original Irish source material is mine). Ó Cadhain's unpublished article in this correspondence is held in The Papers of Muiris Ó Droighneáin, UCD Archives, P154/90 (4). In its March 1963 edition An tUltach carried two letters responding to the controversy, one from an individual using the pseudonym 'Dubliner' which, while deferential towards Ó Cadhain, makes a case for the need for standard Irish. The other letter was from the writer Breandán Ó hÉithir (1930-1990), who was quite contemptuous of Ó Droighneáin's views.

${ }^{2}$ There are several biographical works on Ó Cadhain in Irish (Ó Cathasaigh (2002), Costigan \& Ó Curraoin (1987), Titley (1975)) as well as the entry on Ó Cadhain in the digitised biographical database www.ainm.ie. The key sources in English are McGuire \& Quinn ed. (2009) and Welch ed. (1996). Inevitably, given Ó Droighneáin's more modest profile, he figures much less prominently in biographical sources. Besides the entry for Ó Droighneán in www.ainm.ie, the descriptive catalogue of The Papers of Muiris Ó Droighneáin in UCD Archives (IE UCDA
} 
1970. He was a lifelong Republican Socialist who was one of up to 1,000 IRA men who spent the years of the Second World War in internment camps, the government of 'Eire' having deemed the IRA a threat to national security. On his release from the Curragh prison camp Ó Cadhain became first a government translator (1947-56), then lecturer, and finally Professor of Irish at Trinity College Dublin. More importantly, he published some of the finest prose works in Modern Irish, particularly the novel Cré na Cille ('Churchyard Clay') in 1949. Ó Cadhain was also a relentless social campaigner for the rights of the people of the Gaeltacht and it is often remarked that the huge amount of time and energy he devoted to various causes stymied his literary output.

Like Ó Cadhain, Muiris Ó Droighneáin appears to have been a member of at least the junior wing of the IRA, Fianna Éireann, in which he says he was active at some point after the 1916 Rising. $^{3}$ Ó Droighneáin was born in rural Co. Cork in 1901. Although not a native speaker of Irish he remembered his grandparents speaking in Irish and the accompanying sense of frustration of not understanding what they were saying. He went on to learn Irish at school and at University College Cork, where he excelled. Ó Droighneáin spent most of his working life (1931-1970) as a teacher of Irish at St Malachy's College in Belfast, a prestigious Catholic grammar school for boys. An exceptionally zealous advocate of Standard Irish, Ó Droighneáin was renowned for sending a corrected copy of every published book in Irish to its author, paying particular attention to deviations from the Standard. Besides publishing two short dictionaries of terminology and one on personal names, Ó Droighneáin was frequently consulted by the editors of various texts in Modern Irish and is duly credited by Niall Ó Dónaill (1977: vi) in the preface to the latter's landmark Irish-English dictionary and is given special gratitude by the editors of the Christian Brothers' highly popular New Irish Grammar (1990: iv). It is clear that, at least from the late 1950s onwards, Ó Droighneáin had a public role as the 'watchman of the standard', as the writer of his obituary puts it."

P154) is prefaced by a very useful biographical essay and chronology by Lisa T. Collins. A summary of this can be accessed at http://www.ucd.ie/archives/html/collections/odroighneainmuiris.html

${ }^{3}$ Bhí mé féin agus mo dheartháir i bhFianna Éireann ag cuidiú leis na hÓglaigh, 'My brother and I were in Fianna Éireann assisting the IRA' (Ó Droighneáin 1962b: 8).

${ }^{4}$ See Muiris Ó Droighneáin biography in www.ainm.ie. In a private correspondence with Ó Droighneáin Tomás de Bhaldraithe refers to him as "Ireland's chief corrector of Irish" (... phríomhcheartaitheoir Gaeilge na hÉireann; The Papers of Muiris Ó Droighneáin, UCD, P154/220 (21)). It is worth noting that O Droighneáin's manifold corrections of the text of de Bhaldraithe's English-Irish Dictionary (1959) were not acknowledged in the supplement of 'Terminological Additions and Corrections' published in 1978, this in spite of de Bhaldraithe's frequent private acknowledgement of Ó Droighneáin's contribution (The Papers of Muiris Ó Droighneáin, UCD, P154/220 (21)). 
However his assiduous championing of Standard Irish had a more direct and perhaps more productive outlet in his role as a highly respected teacher of Irish whose pupils included a number of leading academics among whom were Proinsias Mac Cana, Gearóid Stockman and Micheál Ó Murchú. ${ }^{5}$ Of these, Stockman and Ó Murchú as Professor of Irish at Queen's University Belfast and Lecturer in Modern Irish at the University of Ulster respectively appear to have applied Ó Droighneáin's zeal for Standard Irish in their own teaching in the two universities of the North of Ireland.

\section{Series of articles on Standard Irish}

Although a certain antagonism towards Ó Droighneáin had been festering within Ó Cadhain for some time, the controversy to be discussed here was sparked off by a mocking reference to a prayer composed by Ó Droighneáin which he used as a signature to his monthly articles on Irish grammar "Eternal Father, in the name of Jesus make Ireland united a Gaeltacht again." ${ }^{6}$ ó Cadhain's parody of the prayer ran thus: "Oh God of standardised languages and editorial English, grant again a Standard to the Gaels of Ireland, a Gaeltacht to all Ireland, but whatever it is makes a Gaeltacht, grant a Standard..." Ó Droighneáin's response was restrained; he gave a brief survey of what he called 'Ó Cadhain's Standard', outlining the main areas where Ó Cadhain's spelling of Irish was at variance with the Standard but pointing out at the same time the greater consistency of Ó Cadhain's approach against some of the inconsistencies of the Standard. Nevertheless, he concluded on a note of mild censure, remarking that, while of some dialectal interest, Ó Cadhain's habit of abbreviating endings which he didn't himself pronounce was offputting to readers.

True to form, Ó Cadhain's reply (1962: 6-7) was a mixture of satire and invective, insight and excursus. Besides claiming that Ó Droighneáin was in the habit of continually phoning Rannóg an Aistriúcháin (the 'Translation Section' of the Civil Service, in which Ó Cadhain had worked from 1947 to 1956), Ó Cadhain remarked that his adversary would do the Irish language a service by leaving it alone and taking up a standardised past-time like golf. Furthermore, what Ó Droighneáin regarded as the 'right and wrong' of the Standard was an illusion; there were three Official Standards prior to which

\footnotetext{
${ }^{5}$ The first director of TG4, Cathal Goan (later director general of RTÉ), and the writer and poet Gréagóir Ó Dúill were also pupils of Ó Droighneáin's.

${ }^{6}$ See for example Ó Droighneáin (1962a). While this antagonism is suggested in Ó Cadhain's claim, mentioned above, about Ó Droighneáin phoning the Translation Branch of the Civil Service where Ó Cadhain had worked, it is worth noting that Ó Cadhain had written a friendly letter to Ó Droighneáin in the previous year in which he discussed the standardisation of placenames, on which subject, Ó Cadhain remarks, they were in great agreement. He also mentions here a long letter in progress to Ó Droighneáin on matters of Irish spelling and syntax (The Papers of Muiris Ó Droighneáin, UCD, P154/ 90).
} 
the Standard consisted of aural spelling, manuscript and book spelling. In any case, Ó Cadhain continued, spelling was mere convention and many historically attested and broadly based conventions had been wrongly discarded by the new Standard.

Perhaps the most telling part of Ó Cadhain's article, however, is where he accuses Ó Droighneáin of preferring his Standard over the people that spoke Irish or over the desire to make Ireland a Gaeltacht, reiterating the sentiment of his parody of Ó Droighneáin's prayer. Giving an example of what he calls 'aural spelling' in the letters written by his emigrant brothers and sisters, he remarks that Ó Droighneáin would have no interest in these people. In Ó Droighneáin's mind, he claims, the dialects of Irish were arranged like the wax statues of Madame Tussaud. The historical continuity and living actuality of Gaeltacht speech is opposed by Ó Cadhain to the fir bhréige or dummies/scarecrows of Ó Droighneáin's Standard.

The third article in this series, and the last with which we shall concern ourselves, contained Muiris Ó Droighneáin's reply to Máirtín Ó Cadhain, subtitled 'Let bravery and certainty be with us', in which Ó Droighneáin made the case for uniformity and certainty in Irish spelling and grammar. In this piece Ó Droighneáin countered the notion that he held an abstract interest in the Irish language by challenging what Ó Cadhain had said about his being indifferent to the plight of emigrants. Citing the case of his own pupils from working class districts of Belfast, Ó Doighneáin claimed that these boys could literally be consigned to the emigrant ship if they did not get a high enough mark in state examinations and, where conflicting rules of grammar and spelling existed in Irish, such a possibility was all the more likely. It was for this reason that Ó Droighneáin encouraged his pupils to practise a rigorous standardised written language if they wanted to succeed in life. This sensible point was almost immediately undermined when Ó Droighneáin claimed that proof readers are responsible for the success of creative writers and that Shakespeare would have failed a university entrance examination on account of his poor spelling - experts had been standardising his work for the past three hundred years to make it readable.

Nevertheless, despite such self-defeating (assuming they were not intentionally tongue-in-cheek) arguments, Ó Droighneáin makes a very instructive point at the beginning of his article which reveals the context for much of his outlook on the question of standardised language. Quoting a speech given by the writer and lexicographer, Niall Ó Dónaill, Ó Droighneáin explained how the word 'republic' had had a magical resonance for all of those engaged in the struggle for independence, a single word which encompassed all of the objectives of the Gael. Whenever that independence was granted for twenty-six Irish counties, however, the magic began to wane when it became clear that a Gaelic Ireland had not been achieved in spite of independence. For 
Ó Droighneáin, the pursuit of an ideal republic was to be superseded by the ideal of an Irish-speaking Ireland and it appears that his great contribution to this aim was the somewhat obsessive advocacy of a unified national standardised language.

\section{The Nationalist project and the 'local organic community'}

Ó Cadhain's contention that Ó Droighneáin was more interested in the abstraction of a standardised language than he was in the real people and communities who spoke Irish reflects one of the perennial contradictions at the heart of the nationalist project, namely, the tendency to elevate the culture of peripheral communities as a national ideal while ignoring the material wellbeing of such communities. In the decades after independence, this Janusfaced approach to the Gaeltacht had become increasingly evident to many and it was an abiding theme in Ó Cadhain's life as a social campaigner and polemicist. Part of his mission became to oppose the abstraction of the culture of the Gaeltacht as a pious cultural standard and to promote instead the view of that culture as an organic entity which was dependent on material well-being for survival and which, rather than being frozen in time, was in a constant state of change and flux in common with any living organism.

In his final essay, part literary treatise part autobiography, Páipéir Bhána agus Páipéir Bhreaca, Máirtín Ó Cadhain (1969: 9) explains that he was a product of what he termed a 'local organic community', a phrase coined from his reading of T.S. Eliot. ${ }^{7}$ His greatest inheritance, he tells us, was the speech of his people, and he had endeavoured to fashion the raw material of this speech into the stylised language of his prose and by so doing to have improved it (Ó Cadhain 1969: 15). Although Ó Cadhain tells us that his own dialect was the basis of his literary expression, the very process involved in fashioning a new literary form was necessarily transformative. Indeed, one of Ó Cadhain's many bugbears was what he regarded as the tendency of folklorists and academics to treat living traditions as things to be embalmed and encased in a mausoleum; death, he remarked, was synonymous with the study of Irish and folklore (Ó Laighin 1990: 151). It was never Ó Cadhain's intention, therefore, to insist on preserving the local dialect in mummified form or to resist innovations which would lead towards a new consensus on

\footnotetext{
${ }^{7}$ See also Titley (1993: 232-3) and Ó Cathasaigh $(2002:$ 6-7, 11) for a discussion of both the origin of this term and Ó Cadhain's reference to its development after Eliot by English writers such as Raymond Williams and Richard Hoggart. Titley regards both 'local organic community' and Ó Cadhain's Irish rendering comhthionól fuinniúil fuinte as an egregious example of the tendency to sentimentalise and generalise the notion of rural community. Conversely, Ó Cathasaigh takes the view that Ó Cadhain's Irish phrase comhthionól fuinniúil fuinte (literally, 'kneaded, kneading community') is an improvement on the original English notion and one which was intended to avoid an idealistic, romantic picture of rural community.
} 
spelling and grammar. Rather, he made many incisive recommendations towards standardisation himself and was enthusiastic about Niall Ó Dónaill's classic essay on the development of Standard Irish, Forbairt na Gaeilge (1951). ${ }^{8}$ Indeed, it appears that he fell out with his own brother Joe when the latter felt he had given in to standardisation and the abandonment of Gaelic script. ${ }^{9}$ Nevertheless, when faced with such a strident advocate of Standard Irish such as Ó Droighneáin who, it seemed to Ó Cadhain, evinced a view of Irish as an abstract construct, Ó Cadhain baulked at this guiltless decoupling of language and community.

The issues outlined here will be familiar to many as part of the movement from Gemeinschaft to Gesellschaft, which is part of the wider history of European civilization. ${ }^{10}$ However, the insights specifically afforded by theorists of nationalism seem to be of the greatest relevance to the contention between Ó Cadhain and Ó Droighneáin. One might well characterise Ó Droighneáin as typifying the move towards an 'imagined community', Benedict Anderson's (1983) famous phrase to describe the creation of modern nations. Uncomplicated by local affinities, Muiris Ó Droighnéain looked to the state as both the regulator and guarantor of an official Standard Irish which would transcend local and dialectal difference in the aim of creating a unified language to which each member of the Irish nation could share allegiance. Hence his frequent phone calls and letters to Rannóg an Aistriúchán (the state Translation Department). Moreover, in his role as an educator, Ó Droighneáin was ideally placed to facilitate a key requisite of modern nation-building as understood by Ernest Gellner, that is to say, the establishment of a standardised idiom for context-free communication. The development of modern nations, Gellner (1983: 57) tells us, depends on the following:

...the general diffusion of a school-mediated, academy-supervised idiom, codified for the requirements of a reasonably precise bureaucratic and technological communication. It is the establishment of an anonymous impersonal society, with mutually substitutable atomised individuals, held together above all by a shared culture of this kind, in place of the previous complex structure of local groups, sustained by folk cultures reproduced locally and idiosyncratically by the micro-groups themselves.

\footnotetext{
8 'The Development of Irish'. See Ó Cadhain's review in Ó Laighin (1990: 191-209).

${ }^{9}$ Interview with Pádraig Ó Baoighill who accompanied Ó Cadhain on his tour of the Donegal Gaeltacht in 1957, where they recorded a great number of stories, much of which has been published in Ó Baoighill (2007).

${ }^{10}$ The categories proposed by Ferdinand Tönnies in his Gemeinschaft und Gesellschaft (1887) are generally translated into English as 'community' and '(civil) society'. See Tönnies (2001).
} 
Inevitably, such a standardised code cannot preserve historical continuity at micro-level. Rather, the emphasis is on the clarity and consistency so prized by Ó Droighneáin as aids to the development of a nationwide, school-mediated Irish. Ó Cadhain on the other hand, despite his avowed commitment to the need for a standardised language was troubled by the lack of fidelity to historical forms. Thus, he criticised Proinsias Mac Cana and Tomás Ó Floinn's Scéalaíocht na Rithe (1956), a modernised retelling of some Old Irish and Middle Irish texts, for discarding forms of speech which still survived in the Gaeltacht and for replacing common speech with civil-service clichés. ${ }^{11}$ Although Ó Cadhain was scathing of academics who spoke disparagingly about 'revivalist Irish', proclaiming that everyone's Irish was revivalist now, one gets the sense that he was fighting a battle on two fronts (Ó Laighin ed. 1990: 90). On the one hand, there were the professors and pedants who seemed to care about little else other than the historic language and on the other hand there were the excesses of revivalism which led to either a fetishisation of or detachment from the living historically-rooted communities in which Irish was spoken. In his private correspondence with Ó Droighneáin before their dispute, Ó Cadhain warns of the dangers of discarding Gaeltacht dialects, which he says would encourage people in the Gaeltacht to abandon the Irish language and to regard it henceforth as merely the responsibility of schools. If this were to happen, Ó Cadhain continues, the Irish language would be dead and any standard would be entirely irrelevant. ${ }^{12}$

\section{The imagined linguistic community}

Ó Droighneáin seemed to embody the ability to imagine a new linguistic community which would place Irish beyond the ties of the local; a Cork man who had learned Cork Irish, he taught himself Ulster Irish which he used, in standardised form, after his move to Ulster. Another example of the propensity of revivalists to imagine a new linguistic community is given by the Belfast poet Ciarán Carson (2004) writing about his father Liam. Liam Carson/Mac Carráin had learned Irish as a second language and was an enthusiastic member of the Gaelic League, through which he formed many relationships. $\mathrm{He}$ was an equally enthusiastic member of the Esperanto Association and corresponded with people around the world. On one occasion Ciarán Carson remembers accompanying his father and brothers on board a Russian ship which had docked in Belfast so that they could have high tea with the captain, an Esperanto enthusiast. Very often the catalyst for such encounters in either Irish or Esperanto was the lapel-ring worn by Irish speakers or the star worn by speakers of Esperanto. These are the 'mutually substitutable atomised

\footnotetext{
${ }^{11}$ Ó Cadhain (1969: 18) and Ó Cadhain Papers TCD, B/57.

12 The Papers of Muiris Ó Droighneáin, UCD, P154/ 90.
} 
individuals, held together above all by a shared culture' of which Gellner speaks. In the case of both urban revivalist Irish and Esperanto both were underpinned by a Utopian ideal, expressed literally in the name of the invented language 'Esperanto' or 'hope'.

It may well be argued that the Utopian universalism of revivalists was essential to the long term survival of the Irish language. While it is clear that Máirtín Ó Cadhain was deeply committed to the integrity of his local community both linguistically and politically, ${ }^{13}$ there can be no doubt that he also shared a belief in the need for a more abstract, utopian ideal and in particular the ideal to which Ó Droighneáin alludes in his essay, summarised in a single word, 'republic'. Hope, according to Ó Cadhain (1966: 1), was the single greatest catalyst for change in Irish history, "Hope is the chain detonation which I see going right back in the history of the country." If it were not for a mindset which ran contrary to reason, he went on to say, the Irish would have long since disappeared from history.

In spite of Ó Cadhain's qualified enthusiasm for standardisation of the Irish language as part of the progression to full independent nationhood (what he called the "vision"), ${ }^{14}$ perhaps the pull of the local was too persistent for him to fully accede to this. This dichotomy is neatly summarised by T. S. Eliot in one of those essays to which Ó Cadhain looked for his understanding of the meaning of tradition: "It is only a law of nature, that local patriotism, when it represents a distinct tradition and culture, takes precedence over a more abstract national patriotism" (1933: 20). ${ }^{15}$ In the process of allowing the nation to appropriate the culture of the local community, to create what has been called a periphery-dominated centre, people from the Gaeltacht had in certain ways more to lose than those from without, such as Muiris Ó Droighneáin. ${ }^{16}$ Ó Cadhain became sufficiently exercised about this to declare, in a letter written in the year before his death, that:

the people of the Gaeltacht and, for that matter, of the whole western side of Ireland must grasp the first opportunity to secede from this meaningless state with its meaningless paraphernalia of ministers, as Biafra seceded from Nigeria and Cuba from senile dependence on America. The Orient and Eastern Europe and other parts of the world will gladly have them. ${ }^{17}$

\footnotetext{
13 "It is almost, but not entirely, true to say that whatever he [Ó Cadhain] did in the public arena he did for the people of the Gaeltacht" (Titley 2011: 293).

${ }^{14}$ See Ó Cadhain 1966.

${ }^{15}$ See also Ó Cadhain 1969: 14.

${ }^{16}$ For a discussion of the concept of periphery-dominated centre, see Declan Kiberd's chapter

'The Periphery and the Centre' in his Inventing Ireland (1996: 481-96).

${ }^{17}$ Letter to the editor of The Irish Press concerning the controversy following the commemoration of Peadar Ó Doirnín in March 1969; Ó Cadhain papers TCD, M/2/46.
} 
Perhaps the origin of this last sentence can be explained in Ó Cadhain's final essay, in which the antagonism between the particular and the general, the local and national, the material and the abstract is especially evident. Ó Cadhain speaks here of travelling to the Orient and Eastern Europe, specifically to Leningrad, Moscow and to the Soviet Republic of Kirghizia. Sitting in the airport in Moscow, he was reminded not of Marx and Lenin nor of Dostoevsky or the great Russian authors but the folktales he had heard as a child at home about the Eastern World. He goes on to describe how his mind had mapped these tales heard in childhood to every hedge and stone in his home locality, so much so that they shaped his mind and person entirely. In an ironic way, the idealised Oriental world of the folktale had become local material reality. Perhaps Ó Cadhain's realisation that he was forever bound to return to the material rather than the ideal is the reason for his choosing a piece of verse by Hugh MacDiarmaid as the last word of his final essay:

The rose of all the world is not for me.

I want for my part

Only the little white rose of Scotland

That smells sharp and sweet-and breaks the heart.

While in MacDiarmaid's verse the paradoxical inversion is that of the national over the global, in Ó Cadhain's case this inversion seems to have been overshadowed by that of the local over the national.

\section{Epilogue}

In 2012 a new revised set of guidelines for the Standard Irish, so beloved by Muiris Ó Droighneáin, was made available as a PDF after a period of consultation (Gramadach na Gaeilge 2012). The new guidelines were the work of a panel of experts appointed by Minister Éamon Ó Cuív, grandson of Éamon de Valera, who had commissioned the first handbook of Standard Irish in 1958. Later that year, in August 2012 under a new minister, Donnchadh Mac Fhionnlaoich, the government Translation Section (Rannóg an Aistriúcháin) published its own revised edition of the original 1958 handbook. This has created an anomalous situation in that both publications were officially commissioned by the Irish government, yet the content of one differs from the other to a significant degree. One wonders how effective either set of guidelines will be when each seems to be in direct competition with the other. A solution may lie in the three-year consultation period which the Translation Section announced with the publication of its new Standard Irish. Yet the period of uncertainty which will accompany the consultation process has led to criticism, particularly among those for whom written Irish is their professional 
field. ${ }^{18}$ One feature worth noting is the tendency of the guidelines commissioned by Ó Cuív to embrace dialectal forms more explicitly than before and, in this way, rather than prescribing specific standard forms, in some places 'dialect-neutral' forms are given. This approach seems to me to reflect a general tendency, encouraged by the growing influence of languageplanning analysis, to accept that speakers of Irish from Gaeltacht areas had never really embraced the Standard Irish that prevailed in schools and the civil service. The criticism has been that native speakers were estranged from written Irish, or what they call 'school Irish', and that this needed to be redressed given the most recent gloomy predictions on the future of the Gaeltacht. ${ }^{19}$ With this in mind, it may appear pragmatic for Standard Irish to admit a greater tolerance of dialectal forms than was previously the case. Notwithstanding this, it would be a dangerous thing to give up on the ideal of a standardised written Irish. The lesson of Ó Cadhain versus Ó Droighneáin, it seems to me, is that, while there will always be antagonism between the material local actuality and the abstract utopian ideal, both may be mutually dependent.

Ulster University

\section{Archival sources}

University College Dublin, ‘The Papers of Muiris Ó Droighneáin', Archives IE UCDA P154.

Trinity College Dublin, ‘The Papers of Máirtín Ó Cadhain', Manuscripts and Archives Research Library, TCD MS 10878.

\section{References}

Anderson, B., 1983, Imagined Communities, London: Verso.

Carson, C., 2004, 'The Language Instinct', The Guardian (01/05/2004).

Christian Brothers, 1990, New Irish Grammar, Dublin: Fallons.

Costigan, B., Ó Curraoin, S., 1987, De Ghlaschloich an Oileáin: Beatha agus Saothar Mháirtin Ui Chadhain [Of Island Limestone: the Life and Work of Mairtín Ó Cadhain], Indreabhán: Cló Iar-Chonnacht.

\footnotetext{
${ }^{18}$ See for example Mac Lochlainn 2012.

${ }^{19}$ See the state-commissioned comprehensive study of the use of Irish in the Gaeltacht, where the authors conclude that, without decisive intervention, the strongest Gaeltacht areas will survive for at most fifteen to twenty years in their current state (Ó Giollagáin \& Ó Donncha 2007: 517).
} 
Eliot, T.S., 1933, After Strange Gods: a Primer of Modern Heresy, London: Faber \& Faber.

Gellner, E., 1983, Nations and Nationalism, Oxford: Blackwell.

Kiberd, D., 1996, Inventing Ireland: the Literature of the Modern Nation, London: Vintage.

Mac Lochlainn, A., 2012, 'Fifty Shades of Gaeilge - Lucht Teanga Céasta idir Dhá Chaighdeán' [Fifty Shades of Irish - Language-Users Tormented between Two Standards], The Irish Times (12/09/2012).

McGuire, J., Quinn, J., eds., 2009, Dictionary of Irish Biography, Cambridge: Cambridge University Press.

Ó Baoighill, P., 2007, Ó Cadhain i dTír Chonaill [Ó Cadhain in Donegal], Dublin: Coiscéim.

Ó Cadhain, M., 1962, 'Gan Rath orthu mar Choinbhinsiúin’ [Conventions that are Useless], An tUltach (Lúnasa), 6-7.

ó Cadhain, M., 1966, An Aisling [The Vision], Dublin: An Coiste Cuimhneacháin Náisiúnta.

Ó Cadhain, M., 1969, Páipéir Bhána agus Páipéir Bhreaca [White Papers and Written Papers], Dublin: An Clóchomhar.

Ó Cathasaigh, A., 2002, Ag Samhlú Troda: Máirtín Ó Cadhain 1905-1970 [Imagining a Fight: Máirtín Ó Cadhain 1905-1970], Dublin: Coiscéim.

Ó Dónaill, N., 1951, Forbairt na Gaeilge [The Development of Irish], Dublin: Sáirséal agus Dill.

Ó Dónaill, N., ed., 1977, Foclóir Gaeilge-Béarla [Irish English Dictionary], Dublin: Oifig an tSoláthair.

Ó Droighneáin, M., 1962a, 'Teagasc agus Foghlaim' [Teaching and Learning], An tUltach (Meitheamh), 12.

Ó Droighneáin, M., 1962b, 'Crógacht is Cinnteacht linn' [Bravery and Certainty with us], An tUltach (Meán Fómhair), 8.

Ó Fiannachta, P. ed., 1981, An Bíobla Naofa [The Holy Bible], Maynooth: An Sagart.

Ó Giollagáin, C., Mac Donncha, S. ed., 2007, Staidéar Cuimsitheach Teangeolaíoch ar Úsáid na Gaeilge sa Ghaeltacht:Tuarascáil Chriochnaitheach [A Comprehensive Linguistic Study of the Use of Irish in the Gaeltacht: Full Report], Galway: Ollscoil na hÉireann Gaillimh.

Ó Laighin, S., ed., 1990, Ó Cadhain i bhFeasta [Ó Cadhain in Feasta], Dublin: Clódhanna Teoranta.

Stockman, G., 'Muiris Ó Droighneáin', An tUltach (Lúnasa), 4.

Titley, A., 1975, Máirtín Ó Cadhain: Clár Saothair [Máirtín Ó Cadhain: a List of Works], Dublin: An Clóchomhar.

Titley, A., 2011, Nailing Theses, Belfast: Lagan Press.

Tönnies, F., 2001, Community and Civil Society, Harris, J., Hollis, M., ed., J. Harris, M. Hollis, trans., Cambridge: Cambridge University Press. 
Welch, R., ed., The Oxford Companion to Irish Literature, Oxford: Oxford University Press.

\section{Electronic sources}

Gramadach na Gaeilge: An Caighdeán Oifigiúil. Caighdeán Athbhreithnithe [The Grammar of Irish: the Official Standard. Revised Standard], 2012, http://www.oireachtas.ie/parliament/media/Final-Version.pdfCaighdeán (accessed 11/06/13).

2011, Stíl Tí an Ghúim [An Gúm House Style, including 'Téacs Caighdeáin Athbhreithnithe 2011'/ 'Text of Revised Standard 2011'] http://www.gaeilge.ie/ dynamic/file/Stil_Ti_an_Ghuim2.pdf (accessed 11/06/13). 